\title{
Academic and socio- cultural constraints faced by international students in Pakistan: A case study of COMSATS University Islamabad, Abbottabad
}

\author{
*Ikram Shah, Department of Development Studies, COMSATS University Islamabad, Abbottabad Campus \\ Abu Turab Khan, Department of Development Studies, COMSATS University Islamabad, Abbottabad Campus \\ Adnan Ahmad Dogar, Department of Development Studies, COMSATS University Islamabad, Abbottabad \\ Campus \\ Noor Elahi, Department of Development Studies, COMSATS University Islamabad, Abbottabad Campus \\ Urvah Rehan, Department of Development Studies, COMSATS University Islamabad, Abbottabad Campus
}

\begin{abstract}
The aim of this study was to disentangle the international students experiences and document the factors affecting their educational progress and adjustment at university level in Pakistan. Findings of the study come from 65 semi-structured interviews conducted with Afghanistan, China, Nigeria, and Gambia national students who are pursuing their degrees in Bachelor of Science (BS), Master of Science (MS) and $\mathrm{Ph} . \mathrm{D}$ program in different fields. The analysis of the empirical data revealed that discrepancies exist among students on the basis of their nationality. The main factors affecting the international student educational progress and adjustment issues were academic factor such as assessment criteria, grading pressure, lack of presentation skills, and understating of student online portal system. Language related difficulties include preparing of written assignment, taking lecture notes, and writing reports scientific reports. In social cultural adjustment interaction with others, unfamiliar to local culture, homesickness, loneliness, unavailability of food variety, and difficulty in participation in recreational activities. International students complained on the lack of basic health facilitation and services, lack of exercise facilities particularly for female students, and lack of career counselling and accommodation facilities in the campus.
\end{abstract}

Keywords: international student, university, factors, academic, social cultural, language barriers

Received: 09.12.2020 $\quad$ Accepted: 24.01.2021 $\quad$ Published: 05.02.2021

\section{INTRODUCTION}

In recent years, the rapid internationalization of higher education has been witnessed all over the world (Byram \& Dervin, 2008; Wu, Garza, \& Guzman, 2015). Particularly, in the last three decades growing body of research and publication has been devoted to the different dimensions of the internationalization of higher education, including faculty members and students mobility, cross broader research and knowledge exchange programs, internationalization of curriculum, and transnational education (Altbach, 2016; de Wit, Hunter, \& Howard, 2015; Fakunle, Allison, \& Fordyce, 2016; Ilieva, Killingley, \& Tsiligiris, 2017; Knight, 2012; Tesar \& Arndt, 2017). Globalization creates abundant new opportunities for universities to expand their academic programs for a wider attraction of international students. The number of international tertiary students has been significantly increased from 2 million in 1998 to 5.3 million in 2017 (OECD, 2019). Most of these students are hosted in developed nations such as United States of America (USA) (24\%), United Kingdom (UK) (11\%) China (10\%), Australia, France and Canada each 7\%, Russia and Germany 6\%, and other countries (23\%) (Institute of International Education, 2017). International students are important for both host and destination countries (Dolby \& Rahman, 2008; OECD, 2013). International students contributed significantly in revenue generation in host countries. For instance, international students contributed approximately $\$ 19$ billion (US dollars) annually each to USA and Australia economy (Australian Education International, 2010; NAFSA, 2010), and \$14 billion (US dollars) to the UK economy (UK Council for International Student Affairs, 2010). Throughout the world, the global growth of international students and the changing environ of marketplace, the higher educational authorities and educational institutions are struggling for restructuring the academic programs, services, and support to make it more student oriented (Bista, 2018). For instance, the higher education institutions in many parts of the world announce their 
"global vision" for attracting more international students such as international students' recruitment, hiring of foreign faculty, scholarships programs, and other on campus healthy activities. Currently, the educational institutions in the world have become more international because on one hand they provide choices to students but on the other hand it is necessity of the time too (Cole, 2017, March 7; Varghese, 2018).

A wealth of literature has documented the international students mobility, especially students who seek to pursue their education outside of their countries (Bhandari \& Blumenthal, 2011; Gürüz, 2011; Wei, 2013). The push-pull factors concept is usually used for explaining the students mobility abroad for seeking education (Eder, Smith, \& Pitts, 2010; Maringe \& Carter, 2007; Mazzarol \& Soutar, 2002). Push factors are those determinants operate or condition exist within home country that push or influence a student decision to move abroad for education. These factors ranging from unviability of desired program in country of origin, lack of access to universities, the poor quality of education, and lack of employability opportunities in the country (Mazzarol \& Soutar, 2002). The pull factors are described those factors which attract a student for education in the host country. These include host country culture, living standards, socio-economic status of host country, improved career prospects, academic prestige and employment and immigration opportunities (bin Basri \& Ramli, 2015; English, Allison, \& Ma, 2016; Liu \& Morgan, 2016; Nguyen, 2013; Spinks, 2016). Some studies have also explored determinants that why a student pursue international study this includes improving of cross-culture knowledge and skills, motivation to learn new ways of thinking and behaving, exploring a different culture, making new friends and acquaintances, increase self-esteem and confidence, and independent life experiences (Andrade, 2006; McClure, 2007).

Like the developed countries, in developing countries strategic efforts have been made to recruiter international students. For instance, the non-English speaking countries like China, Japan, South Korea, Malaysia, Taiwan and India aligned their polices with global ambition to recruit students from other countries (Cole, 2017, March 7; Grove, 2017, December 19). For instance, the rapid economic growth in China has transformed the higher education image of the country in the world. Currently, China is targeting .5 million international students by 2020 which indicating that the country will be the international education hub in near future. China has strengthened and extended its regional relationships under the One Belt, One Road initiative and heavily invested in the recruitment of international students (Cai, 2017; Grove, 2017, December 19; Ministry of Education, 2018). In recent years, the influx of international students has been increased to Taiwan from 6,380 international students in 2001 to 21,005 in 2007 (Ko, 2008). The number of international students has dramatically been increases in Malaysia from 30000 thousand in 2007 to 70000 thousand in 2010 (MOHE, 2010). The number of foreign students in South Korea has also been on increase from 3,373 students in 2000 to 59,194 international students in 2010 (OECD, 2012).

Similarly, in recent past the Higher Education of Pakistan (HEC) polices are aligned with global ambition to recruit foreign faculty and attract international students form the developing and developed nations. Therefore, the Higher Education Commission of Pakistan (HEC) has initiated different scholarships programs for students belong to least developed nations, overseas Pakistani, and other nationals. In 2016, 1225 applications have been received by HEC by overseas Pakistan or foreign nationals for studying in different fields in Pakistan universities (Zakaria, Janjua, \& Fida, 2016). All these international students moving from their place of origin to abroad for pursing their education. However, these international students faced certain difficulties while leaving in host countries. These issues include language barriers, social issues, host culture understanding and adjustment, food intake, financial arrangements, health care problems, and psychological issues. These issues are sometime negatively affecting the academic performance of international students (Poyrazli \& Grahame, 2007; Tseng \& Newton, 2002; Wenhua \& Zhe, 2013; Wu et al., 2015). In Pakistan, the influx of international students is gradually increasing and more students from the least developing and developing countries including Afghanistan, Sudan, Somalia, Nigeria, and China are pursuing their higher education in different Pakistan universities. One argument for this increase is the Government scholarships and students exchange programs with these countries. Therefore, more students are studying in Pakistani higher educational institution than before. Most of these students are pursuing their education in top ranking higher educational institutions such as University of Karachi, Quaide-Azam University Islamabad, COMSATS University Islamabad etc. Although, the educational institutions are committed to provide maximum facilitation and support to these international students however, these students faced certain difficulties during their stay in the host country. The current study aims to shed light on the international students experiences and attempted to disentangle the problems faced by international students during their stay in Pakistan. 


\section{Problems Faced by International Students}

A growing body of literature is documented the problems faced by international students (Andrade, 2006; Liu, 2009; Poyrazli \& Grahame, 2007; Sherry, Thomas, \& Chui, 2010; Sovic, 2009; Tseng \& Newton, 2002; Vitasari, Wahab, Othman, \& Awang, 2010; Wenhua \& Zhe, 2013; Wu et al., 2015). Sandhu (1994) categorized the international students' problems in two categories including intrapersonal and interpersonal problems. Intrapersonal problems are those factors which are originated from the student him/herself such as a sense of inferiority, loss, and uncertainty about the future. Interpersonal issues include issues related to sociocultural adjustment, environment, communication, academic restriction, and lack of social support. International students faced array of problem such as different expectations of faculty (Alim et al., 2015), stressing academic environment (Vitasari et al., 2010), challenging assignments, in-ability to understand and follow lectures, interaction with other classmates (January et al., 2018), and adjustment to the new environment (Ibrahim, Kelly, Adams, \& Glazebrook, 2013). International students faced problems esteeming from adjustment to new culture, empiercing new academic differences, experiencing anxiety about returning home, dealing with financial issues, emotional and cross-cultural issues (Hsu, 2003). Study also identified that international students are vulnerable to certain type of exploitation. For instance, international students are at risk when the quality of education is comprised, and student received low quality education or financially exploited. The international student is also at risk when the educational institution at host country give less preferences to internationalization of education (Altbach \& Teichler, 2001). Foreign students also feel lonely and alienated which create a sense of outsider and resulted the lack of friends and social network, and suffering from cultural adjustment and linguistic problems (McClure, 2007; Sawir, Marginson, Deumert, Nyland, \& Ramia, 2008; Zhou, Jindal-Snape, Topping, \& Todman, 2008). In addition, moving abroad is a very crucial decision for international students because of the social capital they have at their origin such as family members and friends. Therefore, international students sometime feel psychological stress, loneliness, and a sense of loss (Lin \& Yi, 1997). A healthy environment at university and supportive community environ are considered as the important aspect of the mental wellbeing of international students (Sümer, Poyrazli, \& Grahame, 2008). Recently, studies have documented that more international students are suffering from psychological issues than before. For instance, study from United States of America (USA) and United Kingdom (UK) reported that mental well-being of international university students has been deteriorated over the last decade (Collishaw, Maughan, Natarajan, \& Pickles, 2010; Twenge et al., 2010). Lin and Yi (1997) argue that difference in culture may lead to interpersonal conflict among students therefore, international students need to create a balance between host culture and their native culture.

A large stream of literature stresses on the importance of English language proficiency. Studies have identified English Language is a single major hurdle for the success of international students. Studies have identified that English language skills are crucial for the academic and social adjustment of the students (Andrade, 2006; Ibrahim et al., 2013; Sawir, 2005; Yeh \& Inose, 2003; Yoon \& Portman, 2004). The lack of English language skills may not only negatively affect the academic performance of students but adversely impacting the ability of students to engage socially with other students (Yeh \& Inose, 2003). In addition, the lack of English proficiency may put the students at risk to in other academic performances such as less class participation, reading behavior and conversation with fellow students, and will remain very passive in interaction (Sawir, 2005). Studies have also highlighted that spoken language barrier is a common problem among international students than the written English language (Sherry et al., 2010; Sovic, 2009). Those students who are familiar with English language feel comfortable and showed high class participation. The English proficiency helps students to articulate knowledge in classroom or in research papers. However, students who faced academic problem such as teaching method or understanding of lectures have difficulty to adjust in the new environment (Lin \& Yi, 1997). Lee and Rice (2007) argue that though the international students have different backgrounds such as nationality and culture, but their problems are long standing and affecting students consistently. In most cases the educational institutions lay more emphasis on international students to adjust in the new environment and adapt. University considered international students more responsible to change themselves and put less responsibility on educational institutions. Liu (2009) argues that high social connectedness among international students is linked less psychological problems and facilitate student to easily adjust in the new environment. Ying and Han (2006) argue that social ties within host country are very important for international students for overall adjustment of international students. Berry (2005) also noted that international students who received any kind of social support, experienced less acculturative stress and issue in adaptation. 


\section{METHODOLOGY}

The findings of this study are the outcome of mixed method approach to uncover the international students' difficulties experienced there stay in a foreign country. The data was collected through a semi-structured interview conducted with international students in COMSATS University Islamabad, Abbottabad campus. COMSATS University Islamabad (hereafter CUI), Abbottabad campus, Pakistan is a public sector university established in the year 2001. CUI has seven campuses across the country with more than twenty thousand students CUI system. In CUI Abbottabad, more than 5500 thousand are pursuing their degrees at different level in 17 undergraduate and 24 graduate programs. CUI Abbottabad has 575 teaching faculty in which 200 faculty hold Ph.D. degrees in different fields. The campus has one main library, 85 modern laboratories, and conference rooms. CUI has remained the top university in the country in the last few years therefore, the number of students in CUI system has been gradually increasing in the las couple of year. In addition, the share of international students has also been on rise, due to the quality education services, research productivity, and overall campus environment. Currently, students from Afghanistan, China, Kenya, Nigeria, Sudan, and Gambia have pursuing their educational career. Data was purposively collected from students belonged from Afghanistan, China, Sudan, Nigeria, and Sudan. Table 1 represents a short profile of the respondents. The semi-structured interview guide conducted from April to July 2019 comprised of both open-ended and close-ended questions which not only encouraged the respondents but also give an opportunity to interviewees to openly expressed their experiences. During the data collection all the ethical considerations were followed including informed consent from the respondent, confidentiality of the information and personal identity, and aspects of cultural sensitivity. Through electronic device, interviews were recoded which took forty-five minutes to one hour.

In total 65 interviews were conducted with students including both male (54) and female (11) who were pursuing their degrees in Bachelor of Science (BS), Master of Science (MS), and Ph.D. program in the department of Computer Science, Business Administration, Civil Engineering, Pharmacy, Software Engineering, Biotechnology, Environmental Sciences, Electrical Engineering, Chemistry, and Development Studies. Empirical data collected through semi-structured interviews with respondents were transferred into personal computer for analysis. For quantitative data mean and standard deviation were collected to understand the variation in the data while for qualitative data thematic analysis were conducted through matrix analysis. Different themes were developed which show the students experiences and difficulties while studying in COMSATS University Islamabad, Abbottabad campus, Pakistan.

Table 1. Demographic Profile of Respondents

\begin{tabular}{|c|c|c|c|c|c|c|}
\hline \multirow[t]{2}{*}{ Department } & \multicolumn{2}{|c|}{ Gender } & \multirow{2}{*}{$\begin{array}{l}\text { Country of } \\
\text { Origin }\end{array}$} & \multirow{2}{*}{$\begin{array}{l}\text { Age } \\
\text { Range }\end{array}$} & \multirow{2}{*}{$\begin{array}{l}\text { Academic } \\
\text { Program }\end{array}$} & \multirow{2}{*}{$\begin{array}{l}\text { Year of } \\
\text { Studies }\end{array}$} \\
\hline & Male & Female & & & & \\
\hline $\begin{array}{l}\text { Computer Science: R1, R2, R3, R4, } \\
\text { R5, R6, R7, R8, R9 \& R10 }\end{array}$ & 8 & 2 & $\begin{array}{l}\text { Afghanistan } \\
\text { China }\end{array}$ & $20-40$ & $\begin{array}{l}\text { Bachelor \& } \\
\text { Ph.D. }\end{array}$ & $3-4$ \\
\hline $\begin{array}{l}\text { Business Administration: R11, R12, } \\
\text { R13, R14, R15, R16, R17, R18, R19, } \\
\text { R20, R21, R21, R22, R23, R24, R25, } \\
\text { R26, R27, R28 }\end{array}$ & 14 & 4 & Afghanistan & $20-25$ & Bachelor & $1-4$ \\
\hline $\begin{array}{l}\text { Civil Engineering: R29, R30, R31, } \\
\text { R32, R33, R34 }\end{array}$ & 6 & 0 & Afghanistan & $20-25$ & Bachelor & $3-4$ \\
\hline $\begin{array}{l}\text { Pharmacy: R35, R36, R37, R38, R39, } \\
\text { R40, R41, R42, R43, R44, R45 }\end{array}$ & 9 & 2 & $\begin{array}{l}\text { Afghanistan } \\
\text { Sudan }\end{array}$ & $20-40$ & $\begin{array}{l}\text { Bachelor \& } \\
\text { Ph.D. }\end{array}$ & $3-4$ \\
\hline $\begin{array}{lll}\text { Software Engineering: R46, R47, } \\
\text { R48, R49, R50, R51 }\end{array}$ & 5 & 1 & $\begin{array}{l}\text { Afghanistan } \\
\text { Sudan }\end{array}$ & $20-40$ & Bachelor & $2-4$ \\
\hline Biotechnology: R52, R53 & 1 & 1 & $\begin{array}{l}\text { Afghanistan } \quad \& \\
\text { Nigeria }\end{array}$ & $20-40$ & $\begin{array}{l}\text { Bachelor \& } \\
\text { Master }\end{array}$ & $1-3$ \\
\hline Environmental Sciences: R54-R55 & 2 & 0 & Gambia \& Nigeria & $20-40$ & $\begin{array}{l}\text { Master \& } \\
\text { Ph.D. }\end{array}$ & $1-3$ \\
\hline Electrical Engineering: R56, R75 & 2 & 0 & $\begin{array}{l}\text { Afghanistan } \\
\text { China }\end{array}$ & $20-40$ & $\begin{array}{l}\text { Bachelor \& } \\
\text { Ph.D. }\end{array}$ & $2-4$ \\
\hline Chemistry: R58, R59 & 2 & 0 & Nigeria & $25-40$ & Ph.D. & 3 \\
\hline
\end{tabular}




\begin{tabular}{|l|l|l|l|l|l|l|}
\hline & & & & & & \\
\hline $\begin{array}{l}\text { Development Studies: R60, R61, } \\
\text { R62, R63, R64, R65 }\end{array}$ & 1 & $\begin{array}{l}\text { Afghanistan \& } \\
\text { China }\end{array}$ & $20-40$ & $\begin{array}{l}\text { Bachelor \& } \\
\text { Ph.D. }\end{array}$ & $1-4$ \\
\hline
\end{tabular}

\section{RESULTS AND DISCUSSION}

\section{Academic Factors}

The mean scores indicate that assessment criteria, grading pressure, presentation skills, class punctuality, and understanding of students' online portal system (see table 2) are among the main factors that affect the international students' academic performances. These factors were more common at BS and Master level while at Ph.D. level students were least affected. For instance, the online system placed for students' assistance and support on one way facilitates students but on the other hand challenging and pushing students to meet certain deadlines and tasks. Students reported that those who are unfamiliar with information technology and having little know how faced difficulties. For instance, correction in attendance and quizzes and assignment marks took time and sometime the application is declined by the administration if someone failed to apply in given time. The grading criteria of the university is quite challenging and tough. For instance, student required to secure maximum marks in internal fifty percent marks. Therefore, everyone needs to meet certain deadlines and fulfill all the requirements before the final exam. In such case those students who never experienced such system will suffered to secure maximum marks in internal exam.

"I always worried about my presentation skills and fully confident to present idea or work in front of class fellows. Prior to this, I never experienced to present in front of people particular way. I used to learn by heart but at the time of presentation usually I found myself confused in pronouncing scientific words and faced difficulty in linking my sentences".

(R 63: Chines Student, April 2019)

Table 2: The Means of Language Related Difficulties among International Students

\begin{tabular}{|l|l|l|}
\hline Academic Factors & Mean & SD \\
\hline Assessment Criteria & 3.15 & 1.09 \\
\hline Grading Pressure & 3.17 & 1.08 \\
\hline Presentation Skills & 3.18 & 1.13 \\
\hline Classroom arrangement and Activities & 2.45 & 1.00 \\
\hline Meeting Deadlines & 2.00 & 1.00 \\
\hline Class Punctuality & 3.20 & 1.11 \\
\hline Understanding Student Online Portal & 3.07 & 1.03 \\
\hline Submission of Online Assignment & 2.39 & 0.89 \\
\hline
\end{tabular}

In addition, majority of the international students documented that the assessment criteria are transparent but quite complicated. However, for international students, securing marks and taking good grades are not an easy job.

"When I took admission in Biotechnology, I thought that after joining university my focus will be on research only. I will dedicate more time to lab and new experiments. But in orientation session when it was informed that at master level getting to "C grade' (equal to less than $70 \%$ marks) the student will not be allowed to keep his/her education continue. I was really worried and were more conscious about marks".

(R 53: Nigerian Student, June 2019)

Particularly, at master level, there is a criterion than if someone unable to secure seventy percent marks in two subjects in two semesters, will be dropped and will be unable to continue their education. This creates pressure on students to work hard and secure maximum marks to secure their degree. This condition makes the international student more at risk and pushing them to put all their energy in initial semesters otherwise they will be dropped.

\section{Language Barriers Difficulties}

Most of the international students reported language difficulties whiling studying at different levels. The mean score in the Table 3 indicates the level of difficulty of students. The highest level of difficulties was 
experienced in taking lecture notes and written assignment. While the lowest level of difficulty was reported as class participation and discussion in class, comprehending and understanding of lecture, and reading lecture related materials. Most of the international students who experienced English as a medium of instructions for the first time, reported difficulty in their academic progress. For the majority of students' English language proficiency affecting their performance in written assignments, note taking during lecture, oral presentation, class participation, and quiz and written paper exams.

Table 3: The Means of Language Related Difficulties among International Students

\begin{tabular}{|l|l|l|}
\hline Language Related Difficulties & Mean & SD \\
\hline Written Assignment & 3.11 & 1.02 \\
\hline Taking Lecture Notes & 3.12 & 1.07 \\
\hline Attempting Subjective Quiz & 2.98 & 1.03 \\
\hline Writing Reports & 3.00 & 1.05 \\
\hline Class Participation and Discussion in Class & 2.89 & 1.00 \\
\hline Reading Lecture Materials & 2.96 & 1.04 \\
\hline Speaking in Tutorial & 2.91 & 1.04 \\
\hline Comprehending and Understanding Lecture & 2.91 & 1.09 \\
\hline
\end{tabular}

Majority of the international students documented that English proficiency is crucial for all the students whose native language is other than English. Because it is an important skill and communication tools.

"I remembered my first day in Campus, in the very first introductory class, all students introduce him/herself in English. I was worried and feel depressed that what I should do while giving my introduction".

(R 41: Afghani Student, May 2019)

Most of the students highlighted written assignment, taking lecture notes, and attempting subjective exam adversely affected their overall academic performance. Although, the University has introduced the zero-semester course in which basic courses of science and English have been taught for one semester but still most of the students did not show any satisfactory performance in the initial regular semester with only few exceptions.

"When first assignment was given to us after 8 to 10 lectures, I was very confident about of assignment. Although, I took help from my class fellow but on submission date I was reluctant to submit the assignment in a very rough form such as, having no title page, the material I search online was not an appropriate one, and even I did not follow the instructions for format of assignment". Chines

(R 9: Chines Student, June 2019)

The discrepancies exist in experiences among international students for instance, for undergraduate level students written assignment and taking lecture notes were the major issues while for graduate level students writing reports and speaking in tutorial was the major hurdle for MS and Ph.D. students. Majority of the Ph.D. students who had minimum or no prior international exposure were more affected during their initial semester.

"During in Lab experiments the international students who lacked English proficiency were always worried about the morning meeting with instructor or professor because the medium of instructions was English. We always recorded the meeting and then listening it again and again to understand that how once should performed the experiment or operate any instrument".

(R 75: Chines Students, April 2019)

Majority of the international students reported that that due to the language barrier, they always have to translate the instructions into Chinese and then study it which puts an extra burden on them and sometime increased their workload. In addition, there was noticeable differences between the level of language related difficulties among Chines and Afghanistan students, and students belong from Nigeria, Gambia, and Sudan. 


\section{Social and Cultural Challenges}

The level of difficulty faced in social and cultural factors was unfamiliar with local custom, participation in recreational activities, homesickness, and loneliness (see table 4). The mean score indicates that most of the international students perceived these factors as major hurdles for them while staying in Pakistan. For instance, the level of difficulties for Afghanistan students was relatively very low because both the countries shared their boundaries and similarity in culture practices and social arrangements. While for Chines, Sudan, Gambia, and Nigerian students the social arrangements and cultural practices are relatively new to them.

Table 4: Social Cultural Difficulties

\begin{tabular}{|l|l|l|}
\hline Social Cultural Factors & Mean & SD \\
\hline Food & 2.45 & 1.17 \\
\hline Homesickness & 2.97 & 1.25 \\
\hline Loneliness & 2.94 & 1.23 \\
\hline Discrimination & 1.54 & 0.89 \\
\hline Interaction with others & 3.16 & 1.27 \\
\hline Unfamiliar to local culture & 3.08 & 1.13 \\
\hline Classroom arrangements & 2.42 & 1.19 \\
\hline Participation in Recreational Activities & 3.05 & 1.2 \\
\hline Co-education & 1.85 & 1.00 \\
\hline $\begin{array}{l}\text { Performing Cultural and Religious } \\
\text { Activities }\end{array}$ & 2.26 & 1.16 \\
\hline
\end{tabular}

Most of the students documented that they feel alienated and loneliness in the beginning. Because it was a new environment for them, and they have little or no familiarity with the local culture. Although, the university administration, faculty, and fellow students welcomed us but adjustment in this new environ was big challenge. Majority of the international students suffered from homesickness and loneliness which they perceived as a common problem among students during initial days however, after passing a semester or two students gradually adjusted to the new environment and cope up with this problem.

"I do miss my family particularly my mother, home environment, and my friends. When I missed them, I called them and talked to them to feel myself not lonely and away from home. I never thought that I will go far away from them. Sometimes, it is really hard".

(R 21: Afghani Student, June 2019)

Students belonged from China, Sudan, Nigeria, and Gambia noted that the understanding of local culture on way created opportunities to interact with local culture and people but on other hand in initially days they were too sensitive to very little things.

"We are foreign to local culture. At the beginning understanding of cultural differences affected our study. We are mostly an our apartment discussed the local culture practices and traditions, which I think created an extra burden for us in those initial days. But now I am fine and happy to experience a new culture".

(R 45 Nigerian Student, June 2019)

Such as, how to interact with opposite gender, participating in small gathering and attending in parties. In addition, Chines students complained on the availability of food varieties at campus level. The food intake of Chines students was relatively different than the rest of the students. For instance, students belonged from Afghanistan, Sudan, and Nigeria have little complained about available food option.

"Being international students, we are living in an apartment inside the campus. There are two canteens in campus, but we are rarely taking our food there. Because we are not used to take these variety of food. Sometime, with other students we go there but never enjoyed our food".

(R 9: Chines Student, June 2019)

\section{Facilitation and Difficulties}

The interviews conducted with international students indicate that the lack of exercise facility, appropriate health care services and facilitation, food availability to international students, and accommodation facility (see table 5) are the major difficulty. Majority of the students reported due to the culture barrier female 
students are not allowed to do outdoor exercise. The university has neither allocated a specific location or area for female students exercise nor having any indoor facility. The male students also reported that in campus there is no gym facility available. A small clinic has been established for providing basic health care services to students but after official time no one is appointed to provide health assistance in case of emergency. Majority of students complained that most of the international students are allocated an apartment of two rooms for six students while the capacity of each room is two persons only. We have complained to administration several times but yet no action has been taken.

Table 5: Facilitation and Resources within the Campus for International Students

\begin{tabular}{|l|l|l|}
\hline Facilitation and Resources & Mean & SD \\
\hline Research Facility & 2.11 & 0.92 \\
\hline Health Care Services and Facilitation & 2.86 & 1.03 \\
\hline Transport Facilitation & 2.35 & 0.99 \\
\hline Accommodation Facility & 2.87 & 1.00 \\
\hline Exercise Facilitation and Resources & 3.01 & 1.14 \\
\hline Availability of Important Information & 2.16 & 1.01 \\
\hline Library and Discussion Rooms Facility & 2.08 & 0.96 \\
\hline Internet Facility and Resources & 2.17 & 0.81 \\
\hline Counselling Facility & 2.99 & 1.14 \\
\hline
\end{tabular}

Majority of the students complained that while living in foreign country, most of the international students suffered from homesickness, feel loneliness and many psychological problems. In campus there is no counselling facility available for students. When we faced some problems, we sometimes discussed with seniors or some faculty member who understand our problems. In very recent years, the number of international students is gradually increasing in the country therefore it is very imperative to having such kind of facility at campus which will definitely not facilitating the students but will also help the institution to understand the international students' problems and better plain for future.

\section{CONCLUSION}

The international students experienced show that majority of students whose native language is other than English or those who never experienced English as a medium of instructions faced difficulty in their academic career. Reportedly, the English proficiency was of one of the important factors that negatively contributing to the academic progress. Students language competence particularly the expressive and written language skills play crucial role in their academic progress and social cultural adjustment. Among international students, the experienced vary by country of origin. Students belong from Afghanistan faced relatively least difficulty than the Chines, Sudanese, Nigerian, and Gambian students. The reason is the similarity in culture and social arrangements of both countries. Therefore, students from Afghanistan have reportedly little complained on the food variety availability, and social cultural factors. However, students from Afghanistan suffered from academic factors and language barriers. These students felt pressure to secure maximum marks, faced difficulties in understating lectures and reading materials. Among Chines students, unavailability of food variety, language barriers, lack of exercise facilities for female students, and attending and participation in students' gatherings were major difficulties they experienced. For Sudanese, Gambian, and Nigerian students, the most common difficulties were the language barriers, social cultural factors, and lack of facilities and services in the campus. Among all international students, academic factors, accommodation issues, and lack of career counseling and exercise facilities were reportedly as the major difficulties experienced by international students.

\section{REFERENCES}

Alim, S. A. H. M., Rabbani, M. G., Karim, E., Mullick, M. S. I., Al Mamun, A., \& Khan, M. Z. R. (2015). Assessment of depression, anxiety and stress among first year MBBS students of a public medical college, Bangladesh. Bangladesh Journal of Psychiatry, 29(1), 23-29.

Altbach, P. G. (2016). Global Perspectives on Higher Education. Baltimore: John Hopkins University Press. 
Altbach, P. G., \& Teichler, U. (2001). Internationalization and exchanges in a globalized university. Journal of Studies in international Education, 5(1), 5-25.

Andrade, M. S. (2006). International students in English-speaking universities: Adjustment factors. Journal of Research in International education, 5(2), 131-154.

Australian Education International. (2010). Export income to Australia from education services in 2009. Research Snapshot. Retrieved from http://aei.gov.au/AEI/PublicationsAndResearch/Snapshots/2010052810 pdf.pdf.

Berry, J. W. (2005). Acculturation: Living successfully in two cultures. International Journal of Intercultural Relations, 29(6), 697-712.

Bhandari, R., \& Blumenthal, P. (2011). International Students and Global Mobility in Higher Education. New York: Palgrave.

bin Basri, \& Ramli, B. T. (2015). Multicultural benefits and challenges for international students during period of their study: Case study in Malaysia. 4(1), 41-54.

Bista, K. (2018). Exploring the field: Understanding the international student experience. Global perspectives on international student experiences in higher. 1-16.

Byram, M., \& Dervin, F. (2008). Students, staff and academic mobility in higher education. Newcastle: Cambridge Scholars Publishing.

Cai, P. (2017). Understanding China's Belt and Road Initiative; Lowy Institute for International Policy: Sydney, Australia.

Cole, J. R. (2017, March 7). Why American universities need immigrants. The Atlantic. Retrieved from www.theatlantic.com/ education/ archive/ 2017/ 03/ american- universities- need- immigrants/ $518814 /$

Collishaw, S., Maughan, B., Natarajan, L., \& Pickles, A. (2010). Trends in adolescent emotional problems in England: a comparison of two national cohorts twenty years apart. Journal of child psychology psychiatry, 51(8), 885-894.

de Wit, H., Hunter, F., \& Howard, L. (2015). Internationalisation of higher education. Brussels: Policy Department B: Structural Cohesion Policies, European Parliament.

Dolby, N., \& Rahman, A. (2008). Research in International Education. Review of Educational Research, 78(3), 676-726. doi:10.3102/0034654308320291

Eder, J., Smith, W. W., \& Pitts, R. E. (2010). Exploring factors influencing student study abroad destination choice. 10(3), 232-250.

English, A. S., Allison, J., \& Ma, J. H. (2016). Understanding Western students: Motivations and benefits for studying in China. 4(8), 44-55.

Fakunle, L., Allison, P., \& Fordyce, K. (2016). Chinese Postgraduate Students' Perspectives on Developing Critical Thinking on a UK Education Masters. 5(1), 27-38.

Grove, J. (2017, December 19). China will teach 500,000 international students by 2020. The Times Higher Education . Retrieved from www.timeshighereducation.com/ news/ china- will- teach- 500000international- students-2020.

Gürüz, K. (2011). Higher Education and International Student Mobility in the Global Knowledge Economy. 2nd ed. New York: SUNY Press.

Hsu, P. Y. (2003). An assessment of counseling needs of international students at University of WisconsinStout. Masters of Science thesis, WI University of Wisconsin-Stout, Menomonie.

Ibrahim, A. K., Kelly, S. J., Adams, C. E., \& Glazebrook, C. (2013). A systematic review of studies of depression prevalence in university students. Journal of psychiatric research, 47(3), 391-400.

Ilieva, J., Killingley, P., \& Tsiligiris, V. (2017). The Shape of Global Higher Education: International Mobility of Students, Research and Education Provision. Volume 2. London: British Council.

Institute of International Education. (2017). International scholars total by place of origin. Open Doors Report on International Educational Exchange . Retrieved from www.iie.org/opendoors.

January, J., Madhombiro, M., Chipamaunga, S., Ray, S., Chingono, A., \& Abas, M. J. S. (2018). Prevalence of depression and anxiety among undergraduate university students in low-and middle-income countries: a systematic review protocol. 7(1), 57.

Knight, J. (2012). Student mobility and internationalization: Trends and tribulations. Research in Comparative International Education, 7(1), 20-33.

Ko, S. (2008). International students in Taiwan at an all-time high. Retrieved from http://www.taipeitimes.com/News/taiwan/archives/2008/02/12/2003400913. 
Lee, J. J., \& Rice, C. (2007). Welcome to America? International student perceptions of discrimination. Higher education, 53(3), 381-409.

Lin, J.C. G., \& Yi, J. K. (1997). Asian international students' adjustment: Issues and program suggestions. College Student Journal 31(4), 473-479.

Liu, D., \& Morgan, W. J. (2016). Students' decision-making about postgraduate education at G University in China: The main factors and the role of family and of teachers. 25(2), 325-335.

Liu, M. (2009). Addressing the mental health problems of Chinese international college students in the United States. Advances in Social Work, 10(1), 69-86.

Maringe, F., \& Carter, S. (2007). International students' motivations for studying in UK HE.

Mazzarol, T., \& Soutar, G. N. (2002). "Push-pull" factors influencing international student destination choice. 16(2), 82-90.

McClure, J. W. (2007). International graduates' cross-cultural adjustment: Experiences, coping strategies, and suggested programmatic responses. Teaching in Higher Education, 12(2), 199-217.

Ministry of Education. (2018). Statistics of International Students in China in 2018. Available online: http://www.moe.gov.cn/jyb_xwfb/gzdt_gzdt/s5987/201904/t20190412_377692.

MOHE. (2010). Perangkaan Pengajian Tinggi Malaysia, Kuala Lumpur: Kementerian Pengajian Tinggi Malaysia.

NAFSA. (2010). International students contribute $\$ 18.8$ billion to U.S. economy. Retrieved from http://www.nafsa.org/publicpolicy/default.aspx?id=23158.

Nguyen, C. H. (2013). Vietnamese international student mobility: past and current trends. Asian Education and Development Studies, 2(2), 127-148.

OECD. (2012). Education at a Glance 2012: OECD Indicators. Organisation for Economic Co-operation and Development.

OECD. (2013). Education indicators in focus, How is international student mobility shaping up? (pp. 1-4): OECD Publishing, Paris. Retrieved from

OECD. (2019). Education at a glance 2019: OECD indicators. OECD Publishing.

Poyrazli, S., \& Grahame, K. M. (2007). Barriers to adjustment: Needs of international students within a semiurban campus community. Journal of instructional Psychology, 34(1), 28-46.

Sandhu, D. S. (1994). An examination of the psychological needs of the international students: Implications for counselling and psythotherapy. International Journal for the Advancement of Counselling, 17(4), 229-239.

Sawir, E. (2005). Language difficulties of international students in Australia: The effects of prior learning experience. International Education Journal, 6(5), 567-580.

Sawir, E., Marginson, S., Deumert, A., Nyland, C., \& Ramia, G. (2008). Loneliness and international students: An Australian study. Journal of Studies in international Education, 12(2), 148-180.

Sherry, M., Thomas, P., \& Chui, W. H. (2010). International students: A vulnerable student population. Higher education, 60(1), 33-46.

Sovic, S. (2009). Hi-bye friends and the herd instinct: International and home students in the creative arts. Higher education, 58(6), 747-761.

Spinks, H. (2016). Overseas students: Immigration policy changes 1997-2015. Retrieved from http://parlinfo.aph.gov.au/parlInfo/download/library/prspub/4390265/upload_binary/4390265.p df; fileType=application/pdf.

Sümer, S., Poyrazli, S., \& Grahame, K. (2008). Predictors of depression and anxiety among international students. Journal of Counseling Development, 86(4), 429-437.

Tesar, M., \& Arndt, S. J. P. F. i. E. (2017). Cross-cultural complexities of educational policies. 15(6), 665-669.

Tseng, W.-C., \& Newton, F. B. (2002). International students' strategies for well-being. College Student Journal, 36(4), 591-598.

Twenge, J. M., Gentile, B., DeWall, C. N., Ma, D., Lacefield, K., \& Schurtz, D. R. (2010). Birth cohort increases in psychopathology among young Americans, 1938-2007: A cross-temporal meta-analysis of the MMPI. Clinical psychology review, 30(2), 145-154.

UK Council for International Student Affairs. (2010). International students in the UK: Facts, figures, and fiction. $\quad$ Retrieved from http://www.ukcisa.org.uk/files/pdf/about/internationaleducationfactsfigures.pdf.

Varghese, N. V. (2018). Globalization and cross-border mobility in higher education. 1-9. 
Vitasari, P., Wahab, M. N. A., Othman, A., \& Awang, M. G. (2010). A research for identifying study anxiety sources among university students. International Education Studies, 3(2), 189-196.

Wei, H. (2013). An empirical study on the determinants of international student mobility: A global perspective. 66(1), 105-122.

Wenhua, H., \& Zhe, Z. (2013). International Students' Adjustment Problem at University: A Critical Literature Review. Academic Research International, 4(2), 400-406.

Wu, H.-p., Garza, E., \& Guzman, N. (2015). International student's challenge and adjustment to college. Education Research International, 2015.

Yeh, C. J., \& Inose, M. (2003). International students' reported English fluency, social support satisfaction, and social connectedness as predictors of acculturative stress. Counselling Psychology Quarterly, 16(1), $15-28$.

Ying, Y.-W., \& Han, M. (2006). The contribution of personality, acculturative stressors, and social affiliation to adjustment: A longitudinal study of Taiwanese students in the United States. International Journal of Intercultural Relations, 30(5), 623-635.

Yoon, E., \& Portman, T. A. A. (2004). Critical issues of literature on counseling international students. Journal of Multicultural Counseling Development, 32(1), 33-44.

Zakaria, M., Janjua, S. Y., \& Fida, B. A. (2016). Internationalization of Higher Education: Trends and Policies in Pakistan. Bulletin of Education and Research, 38(1), 75-88.

Zhou, Y., Jindal-Snape, D., Topping, K., \& Todman, J. (2008). Theoretical models of culture shock and adaptation in international students in higher education. Studies in higher education, 33(1), 63-75. 